\title{
Influence of a Large Lake on the Winter Range of a Small Mammal: Lake Michigan and the Silver-Haired Bat (Lasionycteris noctivagans)
}

\author{
Allen Kurta ${ }^{1, *}$, Giorgia G. Auteri ${ }^{2}$, Joyce E. Hofmann ${ }^{3}$, Jean M. Mengelkoch ${ }^{3}$, J. Paul White ${ }^{4}$, \\ John O. Whitaker Jr. ${ }^{5}$, Thomas Cooley ${ }^{6}$ and Julie Melotti ${ }^{6}$ \\ 1 Department of Biology, Eastern Michigan University, Ypsilanti, MI 48197, USA \\ 2 Department of Ecology and Evolutionary Biology, University of Michigan, Ann Arbor, MI 48109, USA; \\ gauteri@umich.edu \\ 3 Illinois Natural History Survey, Prairie Research Institute, University of Illinois Urbana-Champaign, \\ Champaign, IL 61820, USA; hofmann@illinois.edu (J.E.H.); jmengelk@illinois.edu (J.M.M.) \\ 4 Wisconsin Department of Natural Resources, Madison, WI 53707, USA; John.White@wisconsin.gov \\ 5 Department of Biology, Indiana State University, Terre Haute, IN 47809, USA; John.Whitaker@indstate.edu \\ 6 Michigan Department of Natural Resources, Wildlife Disease Laboratory, 4125 Beaumont Road, Room 250, \\ Lansing, MI 48910, USA; CooleyT2@michigan.gov (T.C.); MelottiJ@michigan.gov (J.M.) \\ * Correspondence: akurta@emich.edu; Tel.: +1-734-487-1174
}

Received: 11 March 2018; Accepted: 14 April 2018; Published: 17 April 2018

\begin{abstract}
We examine factors affecting the winter range limit of a migrating mammal, the silver-haired bat (Lasionycteris noctivagans), in states surrounding Lake Michigan, the fourth largest freshwater lake in the world. Using 555 citizen-based captures gathered between 1977 and 2016, we show that silver-haired bats overwinter (December-February) as far north as the 45th parallel, in areas roughly demarcated by the $-12.2^{\circ} \mathrm{C}\left(10^{\circ} \mathrm{F}\right)$ mean daily minimum isotherm for January. Although summering populations adjacent to the lake are dominated by males, wintering animals are predominantly female and presumably migrants from north of Lake Superior. Logistic regression suggests that silver-haired bats are more likely to overwinter in warm areas, in counties near the lake, in urbanized locales, and on the west side of the lake. We believe that these small-bodied, solitary bats are hibernating in buildings and that use of human-made structures has allowed the silver-haired bat to overwinter in regions that are devoid of mines, caves and rock crevices and that are too cold for successful hibernation in trees. Lake Michigan impacts where this animal overwinters, presumably through the moderating influence of the lake on multiple aspects of the surrounding climate and because the shoreline likely is a major migratory pathway.
\end{abstract}

Keywords: Lasionycteris noctivagans; silver-haired bat; range limit; geographic distribution

\section{Introduction}

Documenting the distribution of a species is a necessary first-step in addressing theoretical or applied questions concerning the effects of climate change, invasive species, loss of habitat, or other anthropogenic events [1-3]. In addition, knowledge of the range is critical in directing managers to where they should spend their available time and funds. Nevertheless, actually delimiting a range often is difficult, especially for uncommon taxa or for migratory species that occupy distinctly different geographic areas at different times of the year $[4,5]$.

Among land-dwelling mammals, migration is most frequently conducted by bats, especially those that consume insects and live in temperate zones [6]. The disappearance of flying insects in autumn forces these mammals to migrate varying distances, often to nearby subterranean sites, where 
the bats may remain in a protected environment until spring, or to regions that have more moderate aboveground climates, where the animals alternate bouts of torpor with occasional foraging on warm nights. However, unlike birds that summer in temperate areas, most migrating bats do not travel far, and only a few individuals from a few species make seasonal treks of $1500 \mathrm{~km}$ or more $[7,8]$.

In North America, one of these long-distance migrants is the silver-haired bat (Lasionycteris noctivagans), a small (10-14 g) insectivorous species that occurs from northern Mexico to central Canada, depending on time of year [9]. This mammal is of medical concern, because it has been inordinately implicated in human deaths from rabies [10], and it is of conservation concern, because it is one of the three species of bats most commonly killed at wind farms in North America, with more than 100,000 likely perishing each year [11]. Despite these concerns, biologists know little about the ecology and natural history of silver-haired bats. Other than recent papers dealing with aspects of migration [12-14], published literature specifically devoted to the silver-haired bat in the East is old, serendipitous and largely anecdotal (e.g., [15-17]).

One of the most dominant geographic features in eastern North America is the Laurentian Great Lakes. These lakes are the largest source of fresh water in the world, with a drainage basin that includes about $770,000 \mathrm{~km}^{2}$, or an area greater than the country of France [18]. Lake Michigan is of particular interest, because it extends in a north-south direction for $500 \mathrm{~km}\left(4.5^{\circ}\right.$ of latitude), more than any other lake in the New World, and its shores are used as stopover sites and migratory pathways for birds [19] and bats $[20,21]$.

In the Lake Michigan basin, silver-haired bats are mostly absent in mid-summer (July) from two of the adjacent U.S. states, Illinois and Indiana [21-23], with most of these mammals apparently summering in northern Michigan and Wisconsin and the Canadian province of Ontario, as far north as Hudson Bay $[18,24,25]$. In winter, in contrast, most silver-haired bats in the East are found in the south-central and southeastern United States, where they are missing in summer [9]. In these southern areas, overwintering silver-haired bats roost primarily in trees-under bark, in cracks or hollows, and occasionally exposed on the trunk-where they undergo irregular periods of torpor and feeding [26].

However, the northern edge of the winter range of the silver-haired bat is ill defined. Based on specimens from only 30 locations across North America, Izor [27] suggested that the winter range was limited by temperature to areas south of the $-6.7^{\circ} \mathrm{C}\left(20^{\circ} \mathrm{F}\right)$ mean daily minimum (MDM) isotherm for January (about $40-42^{\circ}$ latitude near Lake Michigan). Multiple factors, though, may determine the northern limit of a species, although influences other than temperature often are not considered [28].

Since the late 1970s, we have accumulated more than 550 records of overwintering silver-haired bats from the four states surrounding Lake Michigan-Illinois, Indiana, Michigan and Wisconsin. These records were based on accidental encounters between silver-haired bats and private citizens, such as bats received by wildlife rehabilitators or those submitted to governmental laboratories for testing for the rabies virus. These observations allowed us to examine the hypothesis of Izor [27] concerning temperature and to perform an exploratory, multivariate analysis to identify additional factors that might affect the presence/absence of this species during winter near Lake Michigan, such as distance from the lake, latitude, and location east or west of the lake.

\section{Materials and Methods}

\subsection{Data Collection}

January is typically the coldest month in north temperate areas [29], and all new records in this paper were obtained during December, January or February, in the 40-year period of 1977 to 2016. Our primary source of information was bats submitted for rabies testing to governmental health laboratories in the four states. Because events surrounding each encounter with a bat were part of a patient's medical record, we were not allowed access to most information. Consequently, we reported only the county of origin, rather than a specific location. Similarly, the date that we used for each 
specimen was the date that the animal was received by the laboratory, which usually was $1-3$ days later than the date on which the bat was first encountered by a citizen. Identification of bats submitted for rabies testing in Illinois was made by J.E.H. and J.M.M.; in Indiana, by J.O.W. and graduate students at Indiana State University; in Michigan, by A.K., T.C. and J.M.; and in Wisconsin, by personnel of the health laboratory. The sex of the animal was routinely recorded, except that of bats examined in Indiana before 2006 and occasionally in all states when only a partial body was submitted. The number of years for which data on rabies submissions was provided varied among states-Illinois, 2006-2016; Indiana, 1977-2014; Michigan, 1978-1982 and 2008-2016; and Wisconsin, 1997-2015. None of the individuals included in our analyses tested positive for the virus.

We supplemented specimens from the rabies laboratories in Illinois, Michigan and Wisconsin with data obtained through other sources that also involved a chance encounter between a bat and a human between 1977 and 2016. For Illinois, we included several animals preserved at the Field Museum of Natural History that were listed in VertNet [30]. For Michigan, these included published accounts [31,32], reports from citizens who provided photographs, and a specimen in the Museum of Zoology at the University of Michigan (\#156445). For Wisconsin, we included a bat in the Zoological Museum of the University of Wisconsin (\#22523) and acquired additional records for 2006-2016 from a database compiled by the Wisconsin Department of Natural Resources [33] from annual reporting forms that were submitted by the 10 wildlife rehabilitators who were licensed by the state to accept bats. These experienced rehabilitators were responsible for determining the species and sex and were requested to indicate why the bat was submitted to their facility. We removed one entry from this database, dated 24 December 2006, because the reason for submission was "failure to thrive," indicating that the bat may have been held captive for an unknown period. In addition, we deleted two records from 10 December 2015, a male and female captured together in a building, because they appeared to match individuals that were received the following day by the state laboratory for rabies testing. Rehabilitating bats is illegal in Illinois and Michigan, and although it is allowed in Indiana, there is no centralized database from which we could extract data. Only two observations in our entire database duplicated animals reported by Izor [27], because most of his records occurred before 1977 and in other parts of the continent.

\subsection{Testing Izor's Hypothesis}

To test Izor's suggested limit [27], we used all records that were obtained through any type of citizen encounter. In formulating his hypothesis, Izor [27] examined the isotherm based on MDM temperatures obtained in January 1931-1960 [34]. This mean temperature is calculated by determining the minimum temperature for each of the 31 days in the month and obtaining an average for each year; the resulting 30 means (one for each year) are then averaged to yield the MDM temperature [35]. Isotherms for the United States, based on these mean temperatures, are mapped at intervals of about $5.6^{\circ} \mathrm{C}\left(10^{\circ} \mathrm{F}\right)$, and only two such isotherms-those representing $-6.7^{\circ} \mathrm{C}\left(20^{\circ} \mathrm{F}\right)$ and $-12.2^{\circ} \mathrm{C}$ $\left(10^{\circ} \mathrm{F}\right)$-are present near Lake Michigan in January [34-36]. We qualitatively compared the location of counties with wintering silver-haired bats to the position of the $-6.7^{\circ} \mathrm{C}$ isotherm for $1931-1960$ that was used by Izor [27], but we also evaluated modern versions of the $-6.7^{\circ} \mathrm{C}$ and the $-12.2^{\circ} \mathrm{C}$ MDM isotherm for January that were constructed by the U.S. National Centers for Environmental Information [36], based on data for the current normal (30-year) period of 1981-2010. Besides covering a more-recent 30-year period, these newer isotherms were created using additional reporting stations and improved computational techniques that accounted for missing values and varying times of observation [37]; these methodological differences alone can result in apparent changes in climatological parameters [38], such as the specific location of a particular isotherm.

\subsection{Modeling}

We performed exploratory analyses and modeled factors underlying the winter distribution of silver-haired bats in the states adjoining Lake Michigan using R (v. 3.4.1) [39]. For consistency in 
method of capture, we limited this analysis to only bats that were tested for rabies (Table S1). We further restricted our database to only bats that were tested in 2001 or later, because national recommendations for prophylaxis after contact with a bat changed at the turn of the century, resulting in a huge upsurge in the number of bats submitted [40]. Deleting data obtained before 2001 eliminated only $19(3.9 \%)$ of the bats that were submitted for rabies testing.

Based on our knowledge of bats and local climate and geography, we examined a suite of variables that included latitude, side of the lake (east or west), distance from Lake Michigan, area of land in each county, total number of bats submitted for testing per county, MDM temperature for January, human population, and amount of developed area. Area of land and the latitude and longitude for the centroid of each county were obtained from the U.S. Census Bureau [41], and we visually confirmed the position of the centroid in Google Earth. For some counties along the shores of the Great Lakes, the available centroid obviously included land under the lake, and in these instances, we estimated the position of the centroid for only the mainland portion of the county. Using the ruler tool in Google Earth, we then determined the minimum distance from the centroid to the shore of Lake Michigan. Classification of a county as east or west was usually obvious, but Lake Michigan is slightly curvilinear. Consequently, we arbitrarily divided counties south of the lake at $-87.2^{\circ}$ longitude, which was located about $30 \mathrm{~km}$ east of the boundary between Illinois and Indiana, and counties north of the lake by $-86.5^{\circ}$ longitude, which approximated the western border of Schoolcraft County, Michigan.

We obtained the MDM temperature for January 1981-2010 for individual recording stations [42], and if more than one station occurred in a county, we averaged the values. The total number of bats submitted for rabies testing (all species) was included as a potential predictor, because it reflected the varying number of years for which data were available from each state and any differing propensity of counties to test bats for rabies [40]. We also included size of the human population, as of the census in 2010 [43], and amount of developed land in each county. To obtain total developed area, we summed the values for three land-cover categories (developed low intensity, developed medium intensity, and developed high intensity) that were extracted from the National Land Cover Database [44], using the Landscape Ecology Plugin (LecoS v. 2.0.7) for QGIS (v. 2.18.12) [45,46].

We were forced to eliminate counties from southern Illinois and Indiana (latitude of centroid $<41^{\circ}$ $\mathrm{N}$ ), to avoid collinearity issues with distance to Lake Michigan, and we also excluded Dane County, Wisconsin, because it is home to the National Wildlife Health Center, which submits a large number of bats for rabies testing that originate outside the county and state [47]. After eliminating these counties, developed area and human population within a county were highly correlated in the remaining data set (Spearman $r=0.91 ; p<0.0001$ ). Consequently, we combined these variables into an urbanization index, using the values for the first axis of a principal components analysis, which accounted for $96 \%$ of the variance. Afterwards, 25 of the 197 counties with centroids $\geq 41^{\circ} \mathrm{N}$ were removed, either because they did not have a climatological station or because the data were deemed unreliable by the U.S. National Centers for Environmental Information [42]; nevertheless, only two of these counties had a record of a silver-haired bat.

Most counties (92\%) recorded only zero or one overwintering silver-haired bat during 2001-2016, so we modeled presence/absence of silver-haired bats in each county by logistic regression. We fit the full model to our variables, using the generalized linear model function in R [39], with logit links and binomial distributions. We assessed various assumptions with the variable inflation factor (VIF) [48], which gauged collinearity among predictors; the test of Durbin and Watson [49], which evaluated correlation among residuals; and the one-step approximation of Cook's distance [50], which checked for overly influential outliers.

We used stepwise regression for variable selection with the Akaike Information Criterion adjusted for small sample size $\left(\mathrm{AIC}_{\mathrm{c}}\right)$ [51]. The least important predictors were sequentially removed from the model, using backward elimination, until $\mathrm{AIC}_{\mathrm{c}}$ was minimized [52]. We evaluated goodness-of-fit for the final model via the test of Osius and Rojek [53]. We checked the model's predictive power, using three-fold cross-validation with geographic blocking, to counter the spatial autocorrelation that 
is usually present in models with a spatial component [54]; in other words, we examined the model's ability to predict presence/absence in the northernmost $\left(>44.46^{\circ} \mathrm{N}\right)$, central, and lower $\left(<42.87^{\circ} \mathrm{N}\right)$ third of counties when trained on the rest of the data. To quantify performance in each scenario, we examined the area under the receiver operating characteristic curve (AUC), which results from plotting the true versus false positive rate [55]; AUC ranges from 0.5 to 1 , with $\geq 0.80$ indicating a model that appropriately assigns presence/absence [56].

\section{Results}

\subsection{Overall Patterns}

We compiled 555 winter records of silver-haired bats from the four states, based on all encounters with citizens (Figure 1). Of these, 483 (87\%) came from rabies submissions; 58 (10\%), from wildlife rehabilitators; and $14(3 \%)$, from other sources. Of the total, 388 observations (381 rabies and 7 museum specimens) were from Illinois, 36 (all rabies) from Indiana, 17 (11 rabies, 3 photographs, 2 published accounts, 1 museum specimen) from Michigan, and 98 (39 rabies submissions, 58 rehabilitation records, 1 museum specimen) from Wisconsin. The number of reports per county with records varied from 1 to 306 (Cook County, Illinois); the median for those counties having at least one record was 1 bat/county.

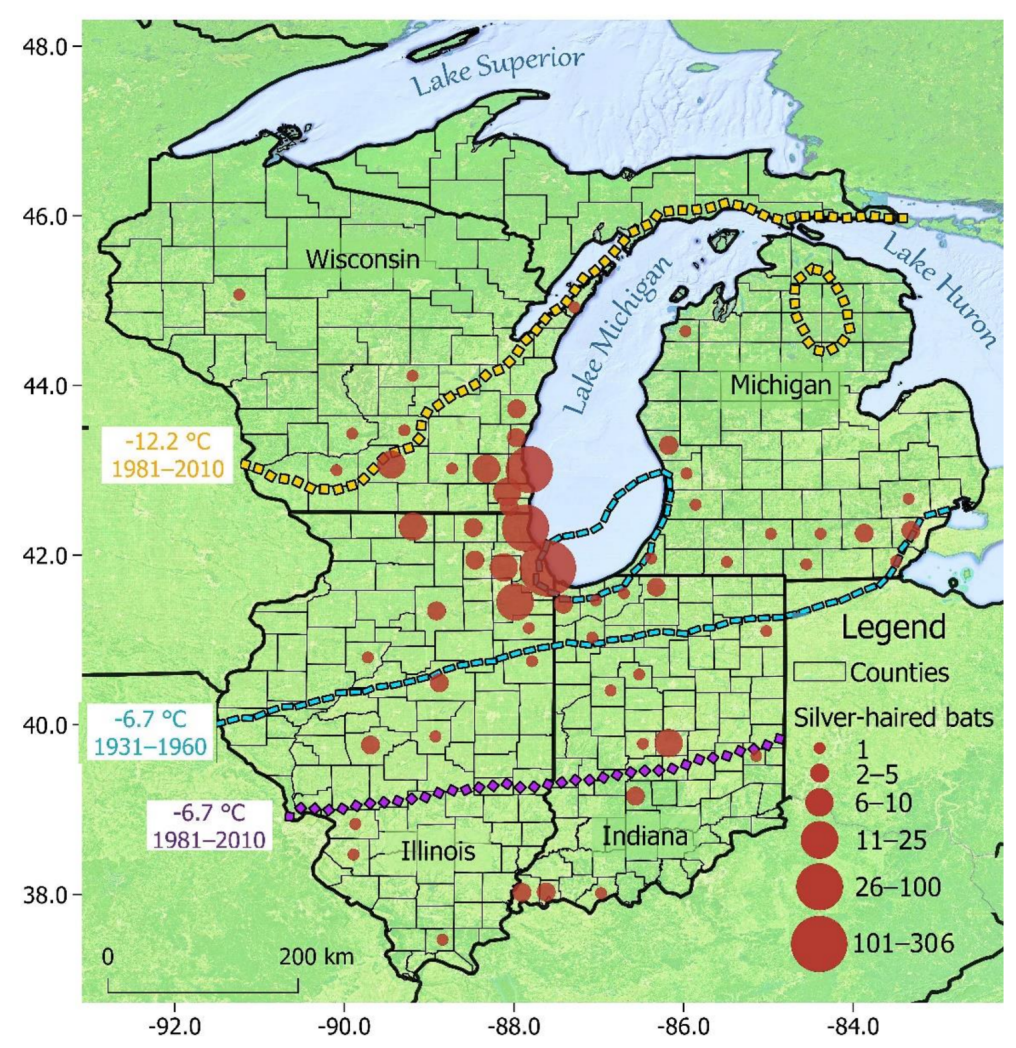

Figure 1. Citizen-based records $(n=555)$ of the silver-haired bat in four states adjoining Lake Michigan, from 1977 to 2016 . The $-6.7^{\circ} \mathrm{C}\left(20^{\circ} \mathrm{F}\right)$ mean daily minimum isotherm for January $1931-1960$ (blue rectangles) [27,34] and for 1981-2010 (purple diamonds) [36] are indicated, as well as the $-12.2^{\circ} \mathrm{C}$ $\left(10^{\circ} \mathrm{F}\right)$ isotherm for 1981-2010 (yellow squares) [36]. Regions north of a particular isotherm for a given time have cooler average temperatures, whereas those to the south are warmer. The blue oval at the southern end of Lake Michigan indicates that the enclosed area was warmer than $-6.7^{\circ} \mathrm{C}$ during 1931-1960, whereas the yellow oval in northern Lower Michigan denotes a region that was cooler than $-12 .{ }^{\circ} \mathrm{C}$ for $1981-2010$. Differences in location of the $-6.7^{\circ} \mathrm{C}$ isotherm for $1931-1960$ versus $1981-2010$ likely reflect use of additional stations and improved computational techniques [37,38]. Degrees of latitude and longitude are noted along the left and bottom of the map, respectively. 
There are 349 counties in the four states, but only $60(17 \%)$ yielded records of overwintering silver-haired bats (Figure 1). These counties were as far south as the Ohio River, whereas the mean latitude of the centroids for the three most northern counties-Door and Chippewa counties, Wisconsin, and Benzie County, Michigan-was $45^{\circ} \pm 0.1^{\circ}(S E)$. Although these bats were detected over a broad area, most of the 555 individuals (63\%) were found in five counties along the southwestern shore of Lake Michigan, from Milwaukee County, Wisconsin, to Cook County, Illinois.

The distribution of citizen-based records among the three months did not differ among the four states $\left(X^{2}{ }_{6}=7.89 ; p=0.25\right)$. Overall, number of observations decreased over the three months, with 220 observations in December, 191 in January, and 144 in February $\left(X^{2}{ }_{2}=15.92 ; p=0.0003\right)$. Sex was available for 505 animals, and most individuals were female $\left(62 \% ; X^{2}{ }_{1}=30.44 ; p<0.0001\right)$. All but one of these encounters with humans involved a single bat, and the exception was the male and female that were taken together in Wisconsin and initially brought to a wildlife rehabilitator.

Records supplied by health laboratories in Illinois, Indiana and Wisconsin provided no information concerning the circumstances under which the animal was encountered (e.g., outdoors, in a cave, in a church, etc.). In Michigan, two of the rabies submissions included the comment "found in house," and 11 animals from Illinois, Michigan and Wisconsin that were documented by publications, photographs or museum specimens apparently were captured in buildings. In Wisconsin, reasons given for admission of 35 of the 58 animals into a rehabilitation facility were nuisance removal from a building. Thus, we know the location of contact for only 48 of the $555(9 \%)$ animals, but all 48 were associated with a building.

\subsection{Testing Izor's Hypothesis}

At least $38 \%$ of our records were in locations with temperatures cooler than suggested by the $-6.7^{\circ} \mathrm{C}$ MDM isotherm for January 1931-1960, and another 58\% were in counties that the isotherm intersected (Figure 1). The location of the $-6.7^{\circ} \mathrm{C}$ MDM isotherm for 1981-2010, calculated from a larger dataset and with improved techniques [36], actually was located about $135 \mathrm{~km}$ south of that based on the older, less-complete recordings from 1931-1960. We obtained 540 animals (97\%) from 52 counties that were located north of the $-6.7^{\circ} \mathrm{C}$ isotherm for January $1981-2010$. The centroids of the three most northern counties with overwintering silver-haired bats were situated 580-650 km north of that current isotherm. The $-12.2^{\circ} \mathrm{C}$ MDM isotherm for January 1981-2010 actually encompassed more locations than the $-6.7^{\circ} \mathrm{C}$ isotherm (Figure 1).

\subsection{Modeling}

For our analysis, we included 172 counties and documented silver-haired bats in 26 (Figure 2). The full model contained no issues of collinearity among predictors (all VIF $<4$ ) or significant correlation among residuals $(p=0.18)$. We discovered no overly influential points, based on Cook's distances $(\leq 0.61)$ and a threshold of 1 to define unacceptable influence [57].

The best-supported model (lowest $\mathrm{AIC}_{\mathrm{c}}$ ) included a significant negative relationship between distance from Lake Michigan and significant positive relationships with total bats submitted, urban index, and temperature; in addition, silver-haired bats were more likely to be found on the west side of the lake (Tables 1-3). The closest competing model, which added the variable area, had a $\Delta \mathrm{AIC}_{\mathrm{c}}$ of 2.1. (Table 2), a deviance that changed minutely after adding area as a variable, and $95 \%$ confidence intervals of the coefficient for area that included zero. Hence, we focused on the simpler model. 


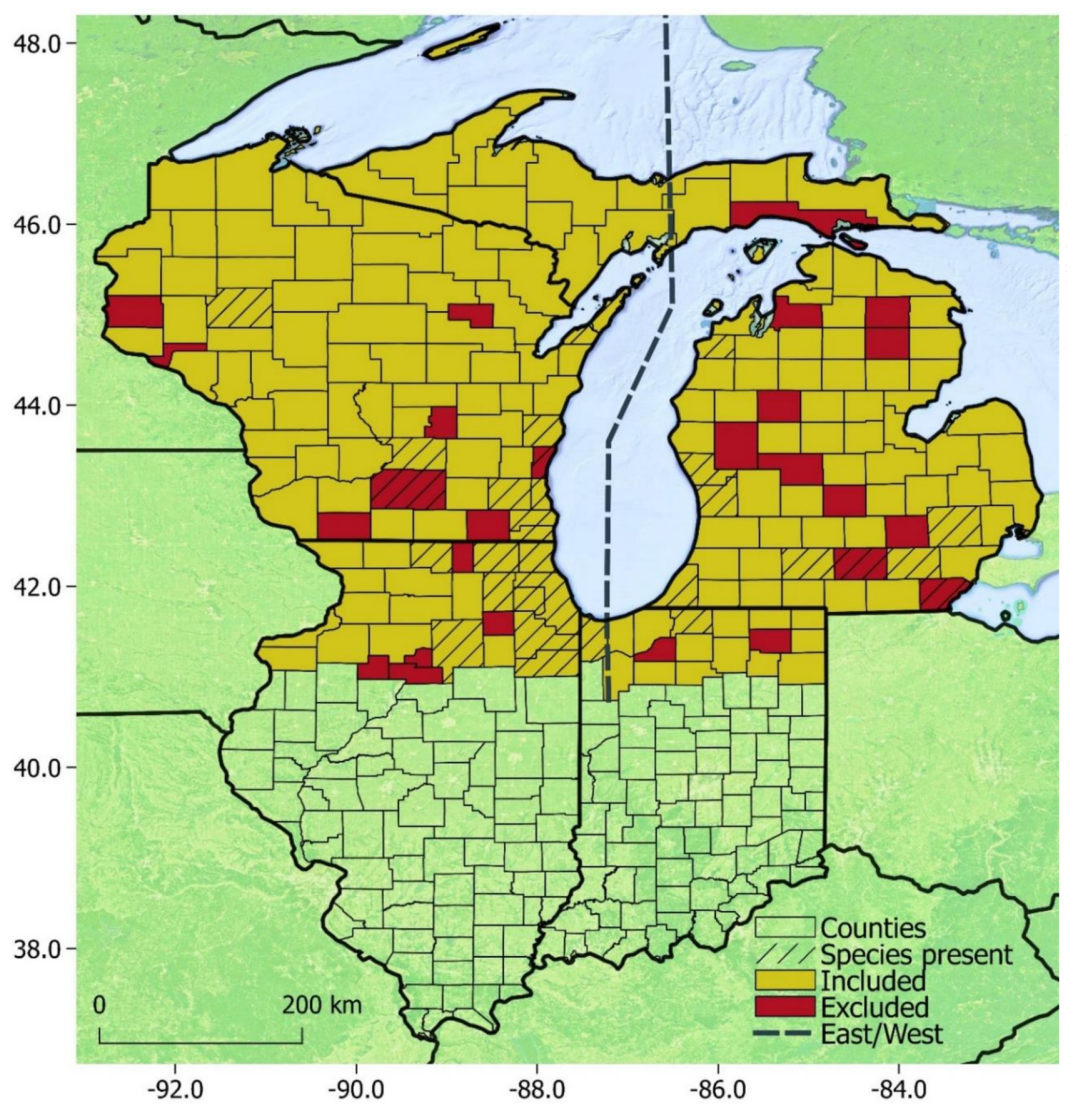

Figure 2. Counties at or above $41^{\circ} \mathrm{N}$ latitude that were included in logistic modeling of presence/absence of silver-haired bats in states surrounding Lake Michigan (yellow). Red counties at or above $41^{\circ} \mathrm{N}$ latitude were excluded, typically because of missing or inadequate climatological data (see text). Cross-hatching indicates counties with at least one record of the silver-haired bat from 2001 to 2016. The boundary for assigning a county to the categories of east versus west of Lake Michigan is also specified. Degrees of latitude and longitude are noted along the left and bottom of the map, respectively.

Table 1. Summary of predictors considered in the full model.

\begin{tabular}{cc}
\hline Predictor & Frequency or Mean (Range); Median \\
\hline Area of land $\left(\mathrm{km}^{2}\right)$ & $1805(626-4717) ; 1570$ \\
Distance to lake $(\mathrm{km})$ & $130.2(4-386) ; 117$ \\
Latitude (degrees) & $43.70(41.03-47.59) ; 43.68$ \\
Side of lake & E: 77 counties W: 95 counties \\
Number of bats submitted/county & $198.9(0-4895) ; 76.5$ \\
Mean daily minimum temperature for January $\left({ }^{\circ} \mathrm{C}\right)$ & $-11.6(-18.4--5.6) ;-11.4$ \\
Urban index & $0.25(-0.53-19.93) ;-0.24$ \\
\hline
\end{tabular}

Table 2. The top competing models selected included the full model, the full model except latitude, and the full model without latitude or area.

\begin{tabular}{ccccc}
\hline Model & d.f. & Log Likelihood & AIC $_{\mathbf{c}}$ & Deviance \\
\hline $\begin{array}{c}\text { Distance from lake + side of lake + number submitted + } \\
\text { urbanization index + temperature }\end{array}$ & 6 & -39.79 & 92.09 & 79.58 \\
\hline $\begin{array}{c}\text { Area + distance from lake + side of lake + number } \\
\text { submitted + urbanization index + temperature }\end{array}$ & 7 & -39.76 & 94.21 & 79.52 \\
\hline $\begin{array}{c}\text { Area + latitude + distance from lake + side of lake + } \\
\text { number submitted + urbanization index + temperature }\end{array}$ & 8 & -39.39 & 95.65 & 78.77 \\
\hline
\end{tabular}


Table 3. Predictors included in the final model and associated coefficients, standard errors, and odds ratios. The odds ratios indicate the change in probability of presence of silver-haired bats per unit of the predictor (e.g., for each increase in $1{ }^{\circ} \mathrm{C}$, the odds of silver-haired bats being present increases 1.198 times or $19.8 \%$.).

\begin{tabular}{cccc}
\hline Predictor & Estimated Coefficient & Estimated Standard Error & Estimated Odds Ratio \\
\hline Distance to lake $(\mathrm{km})$ & -0.014 & 0.005 & 0.986 \\
Side of lake $($ west $=1)$ & 1.914 & 0.794 & 6.783 \\
Number of bats submitted & 0.004 & 0.001 & 1.004 \\
Urbanization index & 0.425 & 0.225 & 1.529 \\
Temperature $\left({ }^{\circ} \mathrm{C}\right)$ & 0.181 & 0.101 & 1.198 \\
\hline
\end{tabular}

The modified Osius-Rojek test indicated no evidence of poor fit $(z \leq 0.0001 ; p=0.99)$. The model made correct predictions for presence/absence over $90 \%$ of the time for middle (AUC $=92.5$ ) and southern (AUC $=90.7$ ) counties. However, the model was less adept at predicting presence/absence in the northernmost counties, when trained on the southern and central counties (AUC $=72.7$ ).

\section{Discussion}

\subsection{Overall Patterns}

The 555 records from December to February greatly exceed those from previous reports that rely on published anecdotes and/or museum specimens [9,27]. Izor [27], for example, reports silver-haired bats in winter from only 30 locations throughout the continent, with only two sites in Illinois, one in Indiana, one in Michigan, and none in Wisconsin. Most of our records are from animals submitted for rabies testing or to wildlife rehabilitators, and use of these resources requires correct identification of the species involved. Silver-haired bats, though, are quite distinct, and misidentifications, especially false positives, are unlikely, even by minimally experienced workers [58].

Most, if not all, silver-haired bats that we report were overwintering in the region. Although a few individuals taken in December may have been late migrants during warm years, $60 \%$ were encountered in January or February, well after autumn migration would have ended. If many were still migrating, we would expect differences in the number of captures during December in Wisconsin and Michigan compared to Illinois and Indiana, but there was no difference among states in citizen encounters during each of the three months. Furthermore, even our three most-northern records, all taken near the 45th parallel and submitted for rabies testing, were received between 3 January and 20 February.

What type of microhabitat are these bats using for hibernation? Although silver-haired bats occasionally overwinter in caves and mines (e.g., [21,59]), this behavior appears uncommon $[26,60]$. In addition, about $90 \%$ of our records occur within $100 \mathrm{~km}$ of the southern half of Lake Michigan (Figure 1), where mines and caves are scarce or nonexistent, the landscape typically is covered by thick glacial till, and even exposed bedrock is rare [61-64]. Some silver-haired bats may overwinter in trees in southern Illinois and Indiana, but this behavior does not seem viable in the colder, northern sections of those states or in most or all of Michigan and Wisconsin, where air temperatures remain below freezing for prolonged periods [65]. Overwintering in trees in northern areas would be more plausible if these small mammals gained extra insulation by clustering with other individuals inside tree hollows, like hibernating common noctules (Nyctalus noctula) in Europe [66] or even homeothermic flying squirrels (Glaucomys volans) in North America [67]. Our data, however, suggest that silver-haired bats are solitary in winter near Lake Michigan, and although more than one of these bats occasionally have been found in the same hibernaculum elsewhere, the animals rarely were in contact with each other [15].

Although we provide information on site of capture for only 48 (9\%) bats, most of which are from Michigan and Wisconsin, all are associated with buildings, and we speculate that most silver-haired 
bats in the four states are hibernating in human-made structures. Such sites may be inside deep cracks, crevices, or expansion joints of large residential, religious, or commercial buildings, similar to those sometimes used by the common noctule in Europe [68], and/or inside the external walls of smaller structures that are internally heated throughout winter, similar to those frequented by big brown bats (Eptesicus fuscus) in the USA [69]. Whitaker and Gummer [70] speculate that use of heated buildings has allowed the big brown bat, which is a sedentary species, to expand its overall range northward, and we suggest that the silver-haired bat, which is a long-distance migrant, has been able to expand its winter range into colder areas of the continent that are devoid of caves and rock crevices by adopting human structures. In states surrounding Lake Michigan, buildings constructed since the time of European settlement presumably have allowed this bat to extend its winter distribution northward, thus enabling some silver-haired bats to perform shorter annual migrations. Nevertheless, all collecting methods are biased, and we cannot exclude the possibility that other silver-haired bats overwinter in cryptic subterranean sites, such as rodent burrows [71].

Most silver-haired bats that summer in the region are male [24]; for example, two mist-netting studies in the Upper Peninsula of Michigan recently yielded a total of 55 silver-haired bats, and all were adult males $[72,73]$. In contrast, our data from citizen encounters indicate that $62 \%$ of the bats that overwinter near Lake Michigan are female. Based on analysis of stable isotopes in hair, Fraser et al. [12] suggest that silver-haired bats exhibit "partial migration," in which some individuals migrate while others are sedentary. Although most females in our study likely summered north of Lake Superior, males may have been either year-round residents of Wisconsin or Michigan or males from farther north that migrated to the vicinity of Lake Michigan.

\subsection{Testing Izor's Hypothesis}

For energetic reasons, the winter range of numerous species of homeothermic birds and mammals and heterothermic bats appears related to temperature, and for some species, the range limit has shown concordance with a particular isotherm [28]. For instance, McNab [74] (p. 140) believes that the common vampire bat (Desmodus rotundus), a tropical species, is limited to areas of Mexico that are south of the $10^{\circ} \mathrm{C}$ "minimal isotherm" for January, and Fenton [75] shows that the eastern small-footed bat (Myotis leibii), a species that hibernates in caves, does not overwinter north of the $-18{ }^{\circ} \mathrm{C}$ MDM isotherm for January in Ontario. Similarly, Izor [27] suggests that hibernation of silver-haired bats in buildings and trees is restricted to parts of the continent south of the $-6.7^{\circ} \mathrm{C}$ MDM isotherm for January. Clearly, though, this is not the case in the central Great Lakes region, where attempted overwintering occurs as far north as the 45th parallel and as much as $650 \mathrm{~km}$ north of the current $-6.7^{\circ} \mathrm{C}$ isotherm (Figure 1). However, the winter limit roughly parallels the $-12.2^{\circ} \mathrm{C}\left(10^{\circ} \mathrm{F}\right) \mathrm{MDM}$ isotherm, especially in Wisconsin, indicating that these bats are hardier than previously believed. The usefulness of this isotherm in predicting presence of silver-haired bats should be tested using citizen-based captures from other states or provinces.

The silver-haired bat has been described as a "quasi-hibernator," because of its frequent feeding activity during winter in the South [76] (p. 2). However, such a characterization does not seem apropos for silver-haired bats overwintering near Lake Michigan, where flying insects are seasonally absent. Instead, this species likely has a continuum of winter strategies, similar to those of the widely distributed big brown bat [77], ranging from frequent arousal and foraging in southern areas to prolonged bouts of torpor and no feeding in the Great Lakes region.

\subsection{Modeling}

Our modeling, though, suggests that several factors help determine where this bat overwinters (Table 3). In addition to MDM temperature for January (Figure 1), distance to the lake is an important predictor of presence/absence, and there likely are multiple reasons for this. First, the lake has a tremendous moderating effect on the winter climate of surrounding regions $[65,78]$. Areas closer to the lake are warmer throughout winter than those farther away, and the warming effect is more 
pronounced for the daily minimum temperature than the maximum; thus, the air temperature in hibernation sites is less likely to go below freezing each night when located near Lake Michigan. Second, the air near the lake contains more moisture [79], which would aid in prolonging torpor by decreasing evaporative water loss [80]. The northward deflection of the $-12.2^{\circ} \mathrm{C}$ isotherm as it approaches the west coast of Lake Michigan (Figure 1) is an example of this moderation of temperature, and isoclines for dew point follow a similar pattern, i.e., they turn distinctly northward near the lake [79]. Third, the lake prolongs the frost-free period in fall, which would allow extended foraging prior to entering hibernation. For instance, average date of first frost for the coastal city of Muskegon, Michigan, is 11 October, but $50 \mathrm{~km}$ farther inland at Newaygo, Michigan, frosts begin two weeks earlier, on 28 September [65]. Finally, although coastal areas are slower to warm in spring, near-shore habitats provide a bountiful source of insects, especially chironomid flies, that are less common inland [81]. These insects hatch early in the season, even before spring leaf-out, and are extensively hunted by insectivorous birds as they migrate along the shores of the Great Lakes [79], as well as by many bats in northern regions when they first leave hibernation $[82,83]$. The only previous comment concerning the potential effect of the Great Lakes on the distribution of bats was by Fenton [75] (p. 3), who reported a few big brown bats and eastern small-footed bats in northern Ontario, near Lake Superior, and stated that their presence "could be attributed to the warming effect of the lake."

Bats often follow maritime coastlines during migration [9,84], and the same appears true for the shores of the Great Lakes (e.g., $[13,20,85])$. If silver-haired bats migrate along the shorelines, then the greater probability of finding these mammals near the coast in winter may also reflect individual tendencies to move inland differing distances after their southward journey has been completed. The greater likelihood of discovering silver-haired bats west of the lake, though, is somewhat surprising, because the moderating effect of Lake Michigan on climate is generally more pronounced eastward (downwind) of the lake [65]. More bats are submitted for testing in counties west of the lake, where there is a greater concentration of urban areas; however, we found no evidence of collinearity among the variables, and the effect of side was significant even though these other variables were included in the model. Inclusion of side in the model, despite the presence of the other variables, suggests that more silver-haired bats migrate along the west rather than the east coast of the lake, as do some birds [86]. The effect of side is quite striking in that no county in Michigan, on the east side of the lake, yielded more than three winter records of silver-haired bats during the entire period of 1977-2016 (Figure 1). Finally, although mist-netting reveals that nocturnal activity of silver-haired bats during summer is negatively correlated with urban development [87], the reverse is true in our study, and the significant urbanization index supports the concept that silver-haired bats near Lake Michigan are using buildings for hibernation and not foraging in winter.

Our model performs well at identifying occupied counties in the southern and central portions of the study area but slightly less so in the north. As Roberts et al. [54] indicate, this reduced predictive power after geographic blocking could result from many factors that are not evident in the overall data set, including complex interactions or non-linear relationships among variables or limiting effects. We speculate that the somewhat poorer performance in the north primarily is due to the cold temperatures and long winters that prevail there [60,65], i.e., virtually the entire northern third of the study area may be unsuitable for overwintering by silver-haired bats, regardless of distance from the lake. Similarly, the lack of highly urbanized counties in the north might limit roosting opportunities needed to overwinter successfully at these colder temperatures. Analyzing citizen-based captures in developed areas that are north of the $-12.2^{\circ} \mathrm{C}$ MDM isotherm for January, such as metropolitan Minneapolis, could help determine whether temperature or urbanization are limiting the northward distribution of this species in winter.

\section{Conclusions}

Silver-haired bats consistently occur much farther north in the central Great Lakes region, and perhaps elsewhere in North America, than previously suspected. We believe that these bats 
use buildings as hibernation sites, thus allowing this mammal to overwinter in areas that are devoid of mines, caves and rock crevices and that are too cold for successful hibernation in trees by a small-bodied, solitary bat. Lake Michigan, the fourth largest freshwater lake in the world, impacts where this animal can be found, presumably through the moderating influence of the lake on multiple aspects of the surrounding climate and because the shoreline may be a major migratory pathway.

Supplementary Materials: The following are available online at http:/ www.mdpi.com/1424-2818/10/2/24/s1, Table S1: Raw Data.

Acknowledgments: In Illinois, the Infectious Disease Laboratories of the Department of Public Health, in Chicago, Springfield, and Carbondale, supplied bats that were examined for rabies and accompanying data, and additional specimens were obtained from the former Animal Disease Laboratories of the Department of Agriculture, in Galesburg and Centralia. In Indiana, data were obtained from the Rabies Laboratory of the State Health Department, and L. Castor of Indiana State University assisted in sorting and organizing that information. In Michigan, D. Freridge, A. Muyombwe, B. A. Robeson and K. Signs of the Department of Health and Human Services provided access to and information concerning bats submitted for rabies testing. In Wisconsin, J. Powell and M. Wedig of the State Laboratory of Hygiene furnished data concerning bats tested for rabies, and information on bats submitted for rehabilitation was supplied by the Wildlife Health Program of the Department of Natural Resources and the licensed rehabilitators of bats in that state. A. Rolfe, J. Rogers and B. A. Schaetz aided in preliminary organization and analysis of data, and R.J. Izor provided background information concerning his earlier investigation of the winter range of silver-haired bats.

Author Contributions: A.K. and J.O.W. conceived the project. A.K. was lead writer, whereas G.G.A. was lead statistical analyst and prepared the figures. A.K., J.E.H., J.M.M., J.O.W., T.C. and J.M. identified bats submitted for rabies testing over multiple years, and all authors contributed to the analyses and helped prepare the manuscript.

Conflicts of Interest: The authors declare no conflicts of interest.

\section{References}

1. Cahill, A.E.; Aiello-Lammens, M.E.; Fisher-Reid, M.C.; Hua, X.; Karanewsky, C.J.; Ryu, H.Y.; Sbeglia, G.C.; Spagnolo, F.; Waldrom, J.B.; Wiens, J.J. Causes of warm-edge range limits: Systematic review, proximate factors and implications for climate change. J. Biogeogr. 2013, 41, 429-442. [CrossRef]

2. Gaston, K.J. Geographic range limits: Achieving synthesis. Proc. R. Soc. B 2009, 276, 1395-1406. [CrossRef] [PubMed]

3. Sexton, J.P.; McIntyre, P.J.; Angert, A.L.; Rice, K.J. Evolution and ecology of species range limits. Ann. Rev. Ecol. Syst. 2009, 40, 413-436. [CrossRef]

4. Martin, T.G.; Chades, I.; Arcese, P.; Marra, P.P.; Possingham, H.P.; Norris, D.R. Optimal conservation of migratory species. PLoS ONE 2007, 2, e751. [CrossRef] [PubMed]

5. McGuire, L.P.; Boyle, W.A. Altitudinal migration in bats: Evidence, patterns, and drivers. Biol. Rev. 2013, 8, 767-786. [CrossRef]

6. Fleming, T.H.; Eby, P. Ecology of bat migration. In Bat Ecology; Kunz, T.H., Fenton, M.B., Eds.; University of Chicago Press: Chicago, IL, USA, 2003; pp. 156-208. ISBN 9780226462073.

7. Cryan, P.M.; Bogan, M.A.; Rye, R.O.; Landis, G.P.; Kester, C.L. Stable hydrogen isotope analysis of bat hair as evidence of seasonal molt and long-distance migration. J. Mammal. 2004, 86, 995-1001. [CrossRef]

8. Hutterer, R.; Ivanova, T.; Meyer-Cords, C.; Rodrigue, L. Bat Migrations in Europe: A Review of Banding Data and Literature; Federal Agency for Nature Conservation: Bonn, Germany, 2005; ISBN 9783784339283.

9. Cryan, P.M. Seasonal distribution of migratory tree bats (Lasiurus and Lasionycteris) in North America. J. Mammal. 2003, 84, 579-593. [CrossRef]

10. Messenger, S.L.; Smith, J.S.; Orciari, L.A.; Yager, P.A.; Rupprecht, C.E. Emerging pattern of rabies deaths and increased viral infectivity. Emerg. Infect. Dis. 2003, 9, 151-154. [CrossRef] [PubMed]

11. Hein, C.D.; Schirmacher, M.R. Impact of wind energy on bats: A summary of current knowledge. Hum.-Wildl. Interact. 2016, 10, 19-27.

12. Fraser, E.; Brooks, D.; Longstaffe, F.J. Stable isotope investigation of the migratory behavior of silver-haired bats (Lasionycteris noctivagans) in eastern North America. J. Mammal. 2017, 98, 1225-1235. [CrossRef]

13. McGuire, L.P.; Guglielmo, C.C.; Mackenzie, S.A.; Taylor, P.D. Migratory stopover in the long-distance migrant silver-haired bat, Lasionycteris noctivagans. J. Anim. Ecol. 2012, 81, 377-385. [CrossRef] [PubMed] 
14. Jonasson, K.A.; Guglielmo, C.C. Sex differences in spring migration timing and body composition of silver-haired bats Lasionycteris noctivagans. J. Mammal. 2016, 97, 1535-1542. [CrossRef]

15. Clark, M.K. A communal winter roost of silver-haired bats, Lasionycteris noctivagans. Brimleyana 1993, 19, 137-139.

16. Kurta, A.; Stewart, M.E. Parturition in the silver-haired bat, Lasioncyteris noctivagans, with a description of the neonates. Can. Field-Nat. 1991, 104, 598-600.

17. Parsons, H.J.; Smith, D.A.; Whittam, R.F. Maternity roosts of silver-haired bats, Lasionycteris noctivagans, in Ontario and Saskatchewan. J. Mammal. 1986, 67, 598-600. [CrossRef]

18. Kurta, A. Mammals of the Great Lakes Region, 3rd ed.; University of Michigan Press: Ann Arbor, MI, USA, 2017; ISBN 978-0-472-05345-2.

19. Archibald, K.M.; Buler, J.J.; Smolinsky, J.A.; Smith, R.J. Migrating birds reorient toward land at dawn over the Great Lakes, USA. Auk 2017, 134, 193-201. [CrossRef]

20. Byre, V.J. A group of young peregrine falcons prey on migrating bats. Wilson Bull. 1990, 102, 728-730.

21. Whitaker, J.O., Jr.; Mumford, R.E. Mammals of Indiana; Indiana Univ. Press: Bloomington, IN, USA, 2009; ISBN 978-0-253-34971-2.

22. Feldhamer, G.A.; Hofmann, J.E.; Carter, T.C.; Kath, J.A. Bats of Illinois; Center for Bat Research, Outreach, and Conservation: Indiana State University, Terre Haute, IN, USA, 2015.

23. Hofmann, J.E.; Merritt, J.F.; Mengelkoch, J.M.; Carpenter, S.K. A two-year mist-netting survey for bats in Cook, DuPage, Kane, Kankakee, Lake, McHenry, and Will counties in northeastern Illinois. Ill. Nat. Hist. Sur. Tech. Rep. 2008, 5, 1-41.

24. Kurta, A. Reproductive timing, distribution, and sex ratios of tree bats in Lower Michigan. J. Mammal. 2010, 91, 586-592. [CrossRef]

25. Naughton, D. The Natural History of Canadian Mammals; University Toronto Press: Toronto, ON, Canada, 2012; ISBN 9781442644830.

26. Perry, R.W.; Saugey, D.A.; Crump, B.G. Winter roosting ecology of silver-haired bats in an Arkansas forest. Southeast. Nat. 2010, 9, 563-572. [CrossRef]

27. Izor, R.J. Winter range of the silver-haired bat. J. Mammal. 1979, 60, 641-643. [CrossRef]

28. McNab, B.K. The Physiological Ecology of Vertebrates. A View from Energetics; Comstock Publishing Associates: Ithaca, New York, NY, USA, 2002; ISBN 978-0801439131.

29. Keen, R.A. Michigan Weather; American \& World Geographic Publishers: Helena, MT, USA, 1993; ISBN 978-0472034130.

30. VertNet. Search VertNet. Available online: http://portal.vertnet.org/search (accessed on 5 April 2018).

31. Gosling, N. Winter record of the silver-haired bat, Lasionycteris noctivagans Le Conte, in Michigan. J. Mamm. 1977, 58, 657-660. [CrossRef]

32. Sherwood, D.E.; Kurta, A. Winter record of the silver-haired bat from Wayne Co. Mich. Birds Nat. Hist. 1999, $6,153-155$.

33. Wisconsin Department of Natural Resources. Wildlife Rehabilitation Annual Report. Available online: http:/ / dnr.wi.gov/files/PDF/forms/2300/2300-302.pdf (accessed on 1 March 2018).

34. U. S. Geological Survey. The National Atlas of the United States of America; U.S. Government Printing Office: Washington, DC, USA, 1970. Available online: https://www.loc.gov/resource/g3701gm.gct00013/?sp=2\& st=gallery (accessed on 1 March 2018).

35. National Centers for Environmental Information. 1981-2010 Climate Normals. Available online: https: / www.ncdc.noaa.gov/data-access/land-based-station-data/land-based-datasets / climatenormals/1981-2010-normals-data (accessed on 1 March 2018).

36. National Centers for Environmental Information. U.S. Climate Atlas. Available online: https://www.ncdc. noaa.gov/climateatlas/ (accessed on 1 March 2018).

37. Arguez, A.; Durre, I.; Applequist, S.; Vose, R.S.; Squires, M.F.; Yin, X.; Heim, R.R., Jr.; Owen, T.W. NOAA's 1981-2010 U.S. Climate Normals: An Overview. Bull. Am. Meteorol. Soc. 2012, 93, 1687-1697. [CrossRef]

38. Hawkins, E.; Sutton, R. Connecting climate model projections of global temperature change with the real world. Bull. Am. Meterol. Soc. 2016, 97, 963-980. [CrossRef]

39. R Core Team. R: A Language and Environment for Statistical Computing. Available online: https://www.rproject.org/ (accessed on 1 March 2018). 
40. Patyk, K.; Turmelle, A.; Blanton, J.D.; Rupprecht, C.E. Trends in national surveillance data for bat rabies in the United States: 2001-2009. Vector-Borne Zoon. Dis. 2012, 12, 666-673. [CrossRef] [PubMed]

41. U.S. Census Bureau. U.S. Gazetteer Files. Available online: https:/ /www.census.gov/geo/maps-data/data/ gazetteer2016.html (accessed on 1 March 2018).

42. National Centers for Environmental Information. Data Tools: 1981-2010 Normals. Available online: https:/ / www.ncdc.noaa.gov/cdo-web/datatools/normals (accessed on 1 March 2018).

43. U.S. Census Bureau. County Population Totals Datasets: 2010-2016. Available online: https://www.census. gov / data/datasets/2016/demo/popest/ counties-total.html (accessed on 1 March 2018).

44. Homer, C.G.; Dewitz, J.A.; Yang, L.; Jin, S.; Danielson, P.; Xian, G.; Coulston, J.; Herold, N.D.; Wickham, J.D.; Megown, K. Completion of the 2011 National Land Cover Database for the conterminous United States-Representing a decade of land cover change information. Photogramm. Eng. Remote Sens. 2015, 81, 345-354. [CrossRef]

45. Jung, M. LecoS-A python plugin for automated landscape ecology analysis. Ecol. Inf. 2016, 31, 18-21. [CrossRef]

46. QGIS Development Team. QGIS Geographic Information System. Open Source Geospatial Foundation Project. Avaliable online: http:/ / qgis.osgeo.org (accessed on 1 March 2018).

47. George, K.G.; U.S.G.S. National Wildlife Health Center, Madison, WI, USA. Personal communication, 2018.

48. Chatterjee, S.; Price, B. Regression Analysis by Example; John Wiley and Sons: New York, NY, USA, 1977; ISBN 0471015210.

49. Durbin, J.; Watson, G.S. Testing for serial correlation in least squares regression, I. Biometrika 1950, 37, 409-428. [CrossRef] [PubMed]

50. Pregibon, D. Logistic regression diagnostics. Ann. Stat. 1981, 9, 705-724. [CrossRef]

51. Burnham, K.P.; Anderson, D.R. Model Selection and Multimodel Inference: A Practical Information-theoretic Approach, 2nd ed.; Springer: New York, NY, USA, 2002; ISBN 0-387-95364-7.

52. Akaike, H. A new look at the statistical model identification. IEEE Trans. Autom. Control 1974, 19, 716-723. [CrossRef]

53. Osius, G.; Rojek, D. Normal goodness-of-fit tests for multinomial models with large degrees of freedom. J. Am. Stat. Assoc. 1992, 87, 1145-1152. [CrossRef]

54. Roberts, D.R.; Bahn, V.; Ciuti, S.; Boyce, M.S.; Elith, J.; Guillera-Arroita, G.; Hauenstein, S.; Lahoz-Monfort, J.J.; Schröder, B.; Thuiller, W.; et al. Cross-validation strategies for data with temporal, spatial, hierarchical, or phylogenetic structure. Ecography 2017, 40, 913-929. [CrossRef]

55. Hosmer, D.W.; Lemeshow, S. Applied Logistic Regression, 2nd ed.; John Wiley \& Sons: New York, NY, USA, 2005; ISBN 9780471356325.

56. Metz, C.E. Basic principles of ROC Analysis. Semin. Nucl. Med. 1978, 8, 283-289. [CrossRef]

57. Cook, R.D.; Weisberg, S. Residuals and Influence in Regression; Chapman and Hall: New York, NY, USA, 1982; ISBN 0-412-24280-0.

58. Streicker, D.G.; Turmelle, A.S.; Vonhof, M.J.; Kuzmin, I.V.; McCracken, G.F.; Rupprecht, C.E. Host phylogeny constrains cross-species emergence and establishment of rabies virus in bats. Science 2010, 329, 676-679. [CrossRef] [PubMed]

59. Pearson, E.W. Bats hibernating in silica mines in southern Illinois. J. Mammal. 1962, 43, 27-33. [CrossRef]

60. Kurta, A.; Smith, S.M.; DePue, J.E. A new northern record for a hibernating silver-haired bat (Lasionycteris noctivagans) in interior North America. Bat Res. News 2017, 58, 23-24.

61. Dorr, J.A., Jr.; Eschman, D.F. Geology of Michigan; University of Michigan Press: Ann Arbor, MI, USA, 1970; ISBN 9780472082803.

62. Dott, R.H.; Attig, J.W. Roadside Geology of Wisconsin; Mountain Press Publishing Company: Missoula, MT, USA, 2004; ISBN 9780878424924.

63. Hall, R.D. Geology of Indiana; Kendall Hunt Publishing: Dubuque, IA, USA, 1989; ISBN 9780840356369.

64. Kolata, D.R.; Nimz, C.K. Geology of Illinois; University of Illinois at Urbana-Champaign: Champaign, IL, USA, 2010; ISBN 9780615417394.

65. Eichenlaub, V.L. Weather and Climate of the Great Lakes Region; University of Notre Dame Press: Notre Dame, IN, USA, 1979; ISBN 9780268019297.

66. Sluiter, J.W.; Voûte, A.M.; van Heerdt, P.F. Hibernation of Nyctalus noctula. Period. Biol. 1973, 75, $181-188$. 
67. Muul, I. Behavioral and Physiological Influences on the Distribution of the Flying Squirrel, Glaucomys volans; Miscellaneous Publications Museum of Zoology, University of Michigan: Ann Arbor, MI, USA, 1968; Volume 134, pp. 1-66.

68. Voigt, C.C.; Phelps, K.L.; Aguirre, L.F.; Schoeman, M.C.; Vanitharani, J.; Zubaid, A. Bats and buildings: The conservation of synanthropic bats. In Bats in the Anthropocene: Conservation of Bats in a Changing World; Voigt, C.C., Kingston, T., Eds.; Springer: New York, NY, USA, 2016; pp. 427-462, ISBN 9783319252209.

69. Halsall, A.L.; Boyles, J.G.; Whitaker, J.O., Jr. Body temperature patterns of big brown bats during winter in a building hibernaculum. J. Mammal. 2012, 93, 497-503. [CrossRef]

70. Whitaker, J.O., Jr.; Gummer, S.L. Hibernation of the big brown bat, Eptesicus fuscus, in buildings. J. Mamm. 1992, 73, 312-316. [CrossRef]

71. Brack, V., Jr.; Carter, J.C. Use of an underground burrow by Lasionycteris. Bat Res. News 1985, 26, 28-29.

72. Kurta, A.; Slider, R. The Bat Community at Pictured Rocks National Lakeshore, with Emphasis on the Northern Long-Eared Bat (Myotis septentrionalis); U.S. National Park Service: Pictured Rocks National Lakeshore, Munising, MI, USA, 2016.

73. Kurta, A.; Schaetz, B.; Slider, R. A Mist-Netting Survey for the Northern Long-Eared Bat, near White Pine, Ontonagon County, Michigan; White Water and Associates: Amasa, MI, USA, 2015.

74. McNab, B.K. Energetics and distribution of vampire bats. J. Mammal. 1973, 54, 131-144. [CrossRef]

75. Fenton, M.B. Distribution and Overwintering of Myotis leibii and Eptesicus fuscus (Chiroptera: Vespertilionidae) in Ontario; Life Sciences Occasional Papers; Royal Ontario Museum: Toronto, ON, Canada, 1972; Volume 21, pp. 1-8. [CrossRef]

76. Davis, A.D.; Morgan, S.M.D.; Dupuis, M.; Poulliott, C.E.; Davis, J.A.; Franchini, R.; Clobridge, A.; Rudd, R.J. Overwintering of rabies virus in silver-haired bats (Lasionycteris noctivagans). PLoS ONE 2016, 11, e015554. [CrossRef] [PubMed]

77. Dunbar, M.B.; Brigham, R.M. Thermoregulatory variation among populations of bats along a latitudinal gradient. J. Comp. Physiol. B 2010, 180, 885-893. [CrossRef] [PubMed]

78. Notaro, M.; Holman, K.; Zarrin, A.; Fluck, E.; Vavrus, S.; Bennington, V. Influence of the Laurentian Great Lakes on regional climate. J. Clim. 2013, 26, 789-804. [CrossRef]

79. Chagnon, S.A., Jr.; Jones, D.M.A. Review of the influences of the Great Lakes on weather. Water Resour. Res. 1972, 8, 360-371. [CrossRef]

80. Kurta, A. The misuse of relative humidity in ecological studies of hibernating bats. Acta Chiropterol. 2014, 16, 249-254. [CrossRef]

81. Ewert, D.N.; Hamas, M.J.; Smith, R.J.; Dallman, M.E.; Jorgensen, S.W. Distribution of migratory landbirds along the northern Lake Huron shoreline. J. Ornithol. 2011, 123, 536-547. [CrossRef]

82. Kurta, A.; Whitaker, J.O., Jr. Diet of the endangered Indiana bat (Myotis sodalis) on the northern edge of its range. Am. Midl. Nat. 1998, 140, 280-286. [CrossRef]

83. Münzer, O.M.; Schaetz, B.A.; Kurta, A. Dietary ecology of a Nearctic species, the evening bat (Nycticeius humeralis), at the northern edge of its range. Acta Chiropterol. 2016, 18, 499-508. [CrossRef]

84. Ijäs, A.; Kahilainen, A.; Vasko, V.V.; Lilley, T.M. Evidence of the migratory bat, Pipistrellus nathusii, aggregating to the coastlines in the northern Baltic Sea. Acta Chiropterol. 2017, 19, 127-139. [CrossRef]

85. Hatch, S.K. Behavior of Migratory Tree Bats in the Western Basin of Lake Erie Using Telemetry and Stable Isotope Analysis. Master's Thesis, University of Akron, Akron, OH, USA, 2015. Available online: https:/ / etd.ohiolink.edu/!etd.send_file?accession=akron1449157127\&disposition=inline (accessed on 1 March 2018).

86. Beebe, R. Influence of the Great Lakes on the migration of birds. Wilson Bull. 1933, 45, 118-121.

87. Coleman, J.L.; Barclay, R.M.R. Urbanization and the abundance and diversity of prairie bats. Urban Ecosyst. 2012, 15, 87-102. [CrossRef]

(C) 2018 by the authors. Licensee MDPI, Basel, Switzerland. This article is an open access article distributed under the terms and conditions of the Creative Commons Attribution (CC BY) license (http://creativecommons.org/licenses/by/4.0/). 